\title{
Formation of glycerine
}

\section{Rochleder}

To cite this article: M. Rochleder (1847) Formation of glycerine, Philosophical Magazine Series 3, 30:199, 146-147, DOI: 10.1080/14786444708645674

To link to this article: http://dx.doi.org/10.1080/14786444708645674

曲 Published online: 30 Apr 2009.

Submit your article to this journal 준

Џll Article views: 2

Q View related articles $₫$ 
terest; the thousandth or even ten-thousandth of a foreign metal is sufficient to cause very characteristic differences in the results of parallel experiments.

A ten-thousandth of lead added to mercury stops its distillation almost entirely. In the following comparative experiments, the mercury which distilled with the greatest difficulty was put into the retort A., which yielded most quickly.

First operation.-Retort A., containing 100 grammes of mercury, to which 1-10,000dth of lead had been added, yielded in a given time by distillation in the bath 5 grammes of mercury.

Retort B., containing the same quantity of mercury without any lead, heated for the same time in the same bath, gave by distillation 67 grammes of mercury.

Second operation.-Retort A., containing 100 grammes of mercury, to which $1-1000$ dth of lead had been added, yielded in a given time by distillation in the bath 2 grammes of mercury.

Retort B., containing the same quantity of mercury without any lead, heated for the same time in the same bath, gave by distillation 55 grammes of mercury.

Zinc was substituted for lead, and when in the proportion of 1-10,000dth, the mercury distilled was to that obtained without the zinc as 6.5 grms. to 72 .

Some metals have no sensible influence on the distillation of mercury : among these are gold, iridium, silver, copper, tin, nickel, cadmium and arsenic. The action of platina is precisely the reverse of that of lead and zinc: it accelerates distillation, but less than lead and zinc retard it; in order that platina may produce this effect, it must be digested in the mercury for a day or two at the temperature of $122^{\circ}$ to $176^{\circ}$ F.-Ann. de Ch. et de Phys., Novembre 1846.

\section{EASY METHOD OF PREPARING IODIDE OF POTASSIUM.}

M. Pypers subjects to a moderate heat a mixture of 100 parts of iodine, 75 of carbonate of potash, 30 of iron filings and 120 of water. 'The mass is to be dried, and then heated to redness; the resulting reddish powder is to be treated with water, and the solution obtained filtered and evaporated to dryness. One hundred parts of iodine yield 135 of very white, but slightly alkaline iodide of potassium.Journ. de Chim. Méd., Decemure 1846.

\section{FORMATION OF GLYCERINE. BY M. ROCHLEDER.}

If castor-oil be dissolved in absolute alcuhol and a current of dry hydrochloric acid gas be directed into the heated solution, the oil undergoes decomposition. When the liquor is agitated with water, after the hydrochloric gas has acted for a sufficient time, an emulsion is obtained, which gradually separates into two portions, one of which is oily and floats, the other is watery and extremely acid; the latter is to be poured off and evaporated by a water-bath. At first hydrochloric acid is disengaged, and there remains a syrupy and yellowish mass 
which is to be treated with rether, which dissolves one portion and leaves another which is insoluble: this last is glycerine, and the solution contains the athers of the fatty acids of the castor-oil.Journ. de Pharm. et de Ch., Decembre 1846.

\section{ON THE COMPOSITION OF BOHEMIAN GLASS.}

According to M. Peligot, the composition of the white Bohemian glass varies but very little in the different manufactories of that country. He has analysed various specimens which were perfectly pure and colourless, and they all yielded very nearly the same results. Their composition was found to be as follows :-

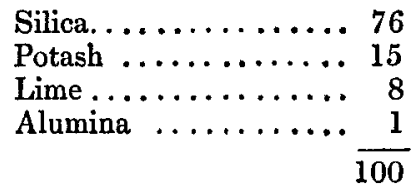

The composition of the verre-agate, or verre de pate de riz of Bohemia is remarkable; it is a simple silicate of potash, the semiopacity of which is derived from imperfect vitrification, which has left grains of quartz, not fused, interposed in the mass. It contains, according to M. Peligot's analysis,-

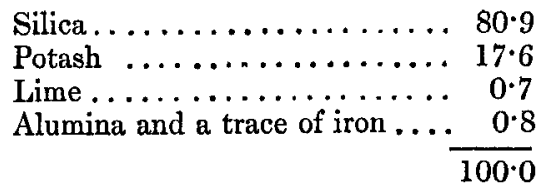

This glass does not attract moisture from the air; when long boiled in water it is not acted upon. It differs from the soluble glass of Fuchs in containing about 10 per cent. more silica.

A specimen of Venetian artificial avanturine yielded-

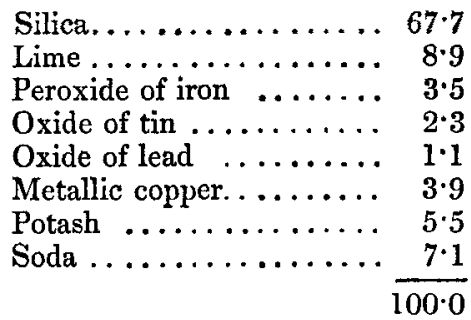

M. Peligot found that a specimen of verre à glaces souflees consisted of-

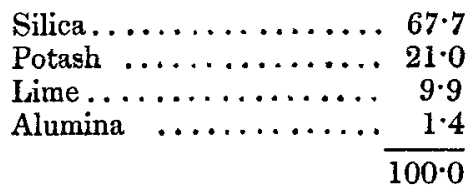

Journ. de Pharm. et de Ch., Novembre 1846. 